Nig. J. Biotech. Vol. 36 (1): 62-68 (June 2019)

ISSN: 01891731

Available online at

http://www.ajol.info/index.php/njb/index

and www.biotechsocietynigeria.org

DOI: https://dx.doi.org/10.4314/njb.v36i1.9

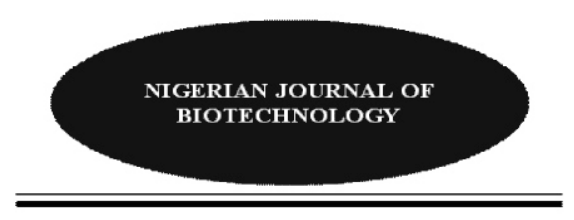

\title{
Genetic diversity in Amaranth (Amaranthus spp.) based on phenotypic and RAPD markers
}

\author{
Oduwaye, O. A. ${ }^{1}$, Ayo-Vaughan, M. A. ${ }^{1}$, Porbeni, J. B. O. ${ }^{1}$ and Oyelakin, 0. O. \\ ${ }^{1}$ Department of Plant Breeding and Seed Technology, Federal University of Agriculture, \\ Abeokuta, Nigeria \\ ${ }^{2}$ Biotechnology Centre, Federal University of Agriculture, Abeokuta, Nigeria
}

Copyright resides with the authors in terms of the Creative Commons License 4.0.

(See http://creativecommons.org/licenses/by/4.0/).

Condition of use: The user may copy, distribute, transmit and adapt the work, but must recognize the authors and the Nigerian Journal of Biotechnology.

\begin{abstract}
Genetic similarities, which can be detected with phenotypic and molecular markers, are important for effective use of available germplasm. It provides information on genetic diversity for reliable gene recombination. Thirty accessions of amaranth were assessed for variation with 15 phenotypic characters and 10 random amplified polymorphic DNA (RAPD) primers. Significant $(p<0.05)$ phenotypic variation was observed among the accession at the vegetative phase and most of the accessions had leaves with green pigmentation. Sink factor such as leaf, stem and root weights, and dry matter, were homogenous traits which contributed significantly to diversity among the accessions. The RAPD primers produced 115 bands with 88 (77\%) polymorphic loci. The DNA classification between some of the accessions was similar to the phenotypic diversity. Information on phenotypic diversity and traits contributing to the diversity can be used deductively with genetic diversity to guide effective hybrid program.
\end{abstract}

Keyword: Accession, genetic divergence, Mahanalobis, oligonucleotide, polymorphism, UPGMA,

Corresponding author: oduwayeoa@funaab.edu.ng

\section{Introduction}

Genetic diversity is an important component in any breeding program and the extent of genetic divergence will determine the limits of selection for improvement. It is indispensable in developing new crop varieties with desirable characters. Therefore, assessment of genetic diversity in available germplasm is important as perquisite for crop improvement. Diversity is usually determined based on morphological characters which include quantitative and qualitative traits (Govindaraj, 2015). However, this approach is not adequate due to small number of phenotypic markers that are usually influenced by environmental factors. However, complementing the morphological information with genetic diversity at the level of DNA would be more reliable. Molecular markers are usually consistent and more accurate because they are unlimited in number and are not affected by environmental factors or developmental stage of the plant (Winter and Kahl, 1995).

Random Amplified polymorphic DNA (RAPD) markers were considered in this study. It uses arbitrary primers that provide a large number of multi-locus markers and has been considered efficient for study of genetic diversity in plants (Chan and Sun, 1997; Mandal and Das, 2002; Fracaro et al., 2005; De Masi et al., 2006; Popa et al., 2010). RAPD is less costly and convenient to generate data faster with less labour compared to other molecular makers.

Amaranths are broad-leafed plants, economic and important vegetable in West Africa (Grubben and Denton, 2004). The genus Amaranthus consist of about 70 species distributed throughout the world. A. cruentus, A. dubius and $A$. tricolor are among the common species cultivated as vegetable in Africa 
(Grubben and Denton, 2004; Maundu et al., 2009). The tender leaves and stem are consumed cooked. It is a nutritious food with high content of protein, vitamins, minerals (Alegbejo, 2013; Shukla et al., 2010). Amaranth is generally management resource-efficient and warm season crop with ability to adapt to heat and drought (Katiyar et al., 2000; Robert et al., 2008).

Despite the nutritional quality and agricultural potential of amaranths, limited attention has been placed on its genetic improvement. This study was carried out to classify thirty accessions of amaranth into distinct groups based on phenotypic and RAPD markers, and to determine characters that are selection criteria to genetic diversity.

\section{Materials and Methods}

Plant materials and field evaluation

A total of thirty accessions of amaranth collected from Germplasm Units of National Centre for Genetic Resources (NACGRAB), Nigeria, National Horticultural Research Institute (NIHORT), Nigeria and Asian Vegetable Research and Development Centre (AVRDC), Tanzania (Table 1) were used in the study. The accessions were evaluated during the late growing seasons of 2010 and 2011 at the Teaching and Research Farm of the Federal University of Agriculture, Abeokuta, Nigeria. Abeokuta is located between Lat $7^{\circ} 10^{\prime} \mathrm{N}$ and $7^{\circ} 58^{\prime} \mathrm{N}$, Long $3^{\circ} 20^{\prime} \mathrm{E}$ and $4^{\circ} 37^{\prime} \mathrm{E}$, and Alt 159 masl.

Randomized complete block design with three replicates was used. The accessions were grown in three-row plots at a spacing of $0.30 \mathrm{x}$ $0.30 \mathrm{~m}$ within and between rows. Seedlings were raised in the nursery with top soils and transplanted to the field at 3 weeks after planting. A plant per hill was maintained at 2 weeks after transplanting to give a total of 15 plants per plot. Inter-plot spacing was $0.50 \mathrm{~m}$. At 5 weeks after transplanting, ten plants were randomly selected per plot and measured for plant height $(\mathrm{cm})$, stem width $(\mathrm{cm})$ at $0.20 \mathrm{~m}$ from soil level, number of leaves; length and width of $3^{\text {rd }}$ leaf from top of the plant $(\mathrm{cm})$, petiole length $(\mathrm{cm})$, leaf area $\left(\mathrm{cm}^{2}\right)$, fresh weights of leaf (including petiole), stem ( $\mathrm{g})$, root $(\mathrm{g})$ and whole plant, and dry matter (g) - $20 \mathrm{~g}$ fresh leaf oven dried at $50^{\circ} \mathrm{C}$ for $12 \mathrm{hrs}$. The following characters were estimated leaf/stem ratio = leaf length $(\mathrm{cm}) / \mathrm{stem}$ width $(\mathrm{cm}) ;$ Specific leaf area = leaf area $\left(\mathrm{cm}^{2}\right)$ / leaf dry matter $\left(\mathrm{cm}^{2} / \mathrm{g}\right)$; Biomass weight as total fresh weight of leaf and stem ( $\mathrm{g})$; Harvest index $=$ Biomass weight $(\mathrm{g}) /$ Whole plant weight $(g)$. Also, the genetic materials were observed for some qualitative traits (Table 1 ).

Data collected were subjected to analysis of variance across the years (genotype and year were considered as fixed factors). Significant effects were separated with Duncan's multiple range test. Mean values of the genotype were subjected to the procedures of principal component, factor and single linkage cluster analyses using statistical analysis system (SAS) ver 9.1.1 (SAS Institute, 2000). Also, FASTCLUS and canonical analysis were performed on the standardized data (mean $=0$; standard deviation $=1$ ) to classify the accessions into distinct groups

\section{$\underline{R A P D \text { analysis }}$}

Leaves of 2 week-old seedlings of ten individuals per accessions were collected for the random amplified polymorphic DNA (RAPD) assays. Genomic DNA was extracted from the fresh leaves with cetyltrimethyl ammonium bromide (CTAB) protocol (Doyle, 1991). A total of 22 oligonucleotide primers with arbitrary sequence were collected from the Biotech Centre Laboratory, International Institute of Tropical Agriculture (IITA), Nigeria and assayed on five randomly selected accessions. A final 10 primers (Table 5) which gave high polymorphism and distinct bands were used for the RAPD analysis. The PCR amplification was performed in $25 \mu \mathrm{l}$ reaction volume with $5.0 \mu \mathrm{l}$ of $25 \mathrm{ng}$ genomic DNA, $1.6 \mu$ l of $25 \mathrm{mM} \mathrm{MgCl}_{2}, 2.0 \mu \mathrm{l}$ of $25 \mathrm{nM}$ 
Oduwaye et al./ Nig. J. Biotech. Vol. 36 Num. 1: 62-68 (June 2019)

Table 1. Qualitative trait and source of thirty amaranth accessions

\begin{tabular}{|c|c|c|c|c|c|}
\hline Accession & Source & Leaf pigmentation & Leaf shape & Leaf margin & Leaf size \\
\hline NG08 & NACGRAB & Green & Elliptical & Entire & Large size \\
\hline NG11 & NACGRAB & Green & Lanceolate & Entire & Large size \\
\hline NG104 & NACGRAB & Green & Elliptical & Entire & Small size \\
\hline NG16 & NACGRAB & Green with pink stripe & Elliptical & Entire & Large size \\
\hline NG27 & NACGRAB & Green & Lanceolate & Entire & Large size \\
\hline NG123 & NACGRAB & Green with pink stripe & Elliptical & Entire & Medium size \\
\hline NG132 & NACGRAB & Green & Lanceolate & Entire & Large size \\
\hline NG141 & NACGRAB & Green & Lanceolate & Entire & Large size \\
\hline NG145 & NACGRAB & Green & Elliptical & Entire & Large size \\
\hline NG174 & NACGRAB & Pink with green strips & Elliptical & Entire & Large size \\
\hline NG184 & NACGRAB & Pink & Elliptical & Entire & Large size \\
\hline NG621 & NACGRAB & Green & Elliptical & Entire & Large size \\
\hline $\mathrm{NH} 86$ & NIHORT & Green & Lanceolate & Undulate & Large size \\
\hline $\mathrm{NH} 117$ & NIHORT & Pink & Elliptical & Entire & Medium size \\
\hline $\mathrm{NH} 120$ & NIHORT & Pink & Lanceolate & Crenate & Large size \\
\hline $\mathrm{NH} 151$ & NIHORT & Pink & Elliptical & Entire & Large size \\
\hline $\mathrm{NH} 161$ & NIHORT & Green & Elliptical & Undulate & Small size \\
\hline $\mathrm{NH} 169$ & NIHORT & Pink & Elliptical & Undulate & Large size \\
\hline NH3194 & NIHORT & Green & Rhombic & Undulate & Large size \\
\hline AM06 & AVRDC & Pink with green strips & Elliptical & Entire & Large size \\
\hline AM11 & AVRDC & Pink & Elliptical & Entire & Medium size \\
\hline AM14 & AVRDC & Green & Elliptical & Entire & Medium size \\
\hline AM18 & AVRDC & Pink & Lanceolate & Entire & Medium size \\
\hline AM19 & AVRDC & Green & Lanceolate & Entire & Medium size \\
\hline AM20 & AVRDC & Pink with green strips & Elliptical & Entire & Large size \\
\hline AM31 & AVRDC & Pink & Elliptical & Entire & Large size \\
\hline AM32 & AVRDC & Pink with green strips & Elliptical & Entire & Medium size \\
\hline AM42 & AVRDC & Green & Lanceolate & Entire & Medium size \\
\hline ACNL & AVRDC & Pink with green strips & Elliptical & Entire & Medium size \\
\hline UG40 & AVRDC & Pink & Elliptical & Entire & Medium size \\
\hline
\end{tabular}

National Centre For Genetic Resources and Biotechnology (NACGRAB), Nigeria National Horticultural Research Institute (NIHORT), Nigeria

Asian Vegetable Research and Development Centre (AVRDC), Tanzania 
dNTPs, $0.5 \mu$ of 1.0 unit Taq DNA polymerase, $1.0 \mu \mathrm{l}$ of a random primer, $2.5 \mu \mathrm{l}$ of $10 x$ buffer $(200 \mathrm{mM}$ Tris- $\mathrm{HCl}, 500 \mathrm{mM} \mathrm{KCl}, \mathrm{pH}$ 8.0) and $12.4 \mu$ distilled deionized water. The PCR amplification was performed with the following cycle: 1 cycle at $94^{\circ} \mathrm{C}$ for $5 \mathrm{~min}$, then 45 cycles at $94^{\circ} \mathrm{C}$ for $1 \mathrm{~min}, 35^{\circ} \mathrm{C}$ for 4 min and $72^{\circ} \mathrm{C}$ for $2 \mathrm{~min}$. The reaction was terminated with a 4min DNA extension step at $72^{\circ} \mathrm{C}$ (Williams et al., 1990). The amplified products were electrophoresed in $1.2 \%$ agarose gels with a $200 \mathrm{bp}$ DNA ladder at $120 \mathrm{~V}$ for $1.5 \mathrm{~h}$ and stained with ethidium bromide. The RAPD profiles were visualized and photographed under ultraviolet light imaging system (Biotechnology Centre, IITA, Nigeria).

Distinct RAPD fragments with the same molecular weight were considered as identical bands, and scored for the presence (1) or absence (0) across the accessions for each primer. The scores were entered into a binary rectangular matrix and Jaccards's coefficient
(Jaccard, 1908) was used to estimate genetic similarity matrix using SIMQUAL program of NTSYS-pc version 2.10 (Rohlf, 1998). The similarities matrix was used to construct a dendrogram using unweighted pair group method based on arithmetic average (UPGMA). Total number of loci, number of polymorphic loci, and allele frequency were determined using POPGEN Version 1.32 software program (Yeh et al., 1997). Polymorphic information content (PIC) was estimated as $2 f i(1$ - fi) where $f i$ is the frequency of the amplified allele of marker $i$ (Roldán-Ruiz et al., 2000)

\section{Results}

The analysis of variance revealed significant variation among the accessions for the characters evaluated (Table 2). The accessions effect varied with year for stem width, petiole length and leaf length. Most of the accessions had leaf and stem with green pigmentation.

Table 2. Mean squares of characters evaluated in amaranth across two years

\begin{tabular}{|c|c|c|c|c|c|}
\hline Source of variation & $\begin{array}{c}\text { Block (year) } \\
(\text { df }=4)\end{array}$ & $\begin{array}{c}\text { Year } \\
(\mathrm{df}=1)\end{array}$ & $\begin{array}{l}\text { Accession } \\
(\mathrm{df}=29)\end{array}$ & $\begin{array}{c}\text { Accession } x \text { Year } \\
(d f=29)\end{array}$ & $\begin{array}{c}\text { Error } \\
(\mathrm{df}=116)\end{array}$ \\
\hline Plant height $(\mathrm{cm})$ & 28.97 & 54.90 & $176.32+*$ & 37.85 & 48.61 \\
\hline Stem width $(\mathrm{cm})$ & $44.02+*$ & $398.93 *+$ & $7.66^{*+*}$ & $6.71+*$ & 2.52 \\
\hline Number of leaves & $294.13^{* *}$ & $357.13 * *$ & 22.41 & 13.15 & 19.57 \\
\hline Petiole length $(\mathrm{cm})$ & $10.49^{*+*}$ & 2.53 & $18.33^{*+}$ & $5.52^{++}$ & 2.80 \\
\hline Leaf length $(\mathrm{cm})$ & 6.83 & $150.73^{* *}$ & $57.77 * *$ & $16.87 * *$ & 8.39 \\
\hline Leaf width $(\mathrm{cm})$ & $5.93+*$ & $20.99^{*+*}$ & $6.63^{*+}$ & 1.66 & 1.63 \\
\hline Leaf/stem & 0.01 & 0.02 & $0.19^{*+*}$ & 0.03 & 0.03 \\
\hline Leaf area & 869.77 & $8569.48 * *$ & $1878.11^{* * *}$ & 576.39 & 402.60 \\
\hline Specific leaf area $\left(\mathrm{cm}^{2 / g}\right)$ & 18.78 & $269.25 *+$ & 80.69 & 107.47 & 70.30 \\
\hline Fresh leaf weight $(\mathrm{g})$ & 6.35 & 2.05 & $64.73^{* *}$ & 10.01 & 6.67 \\
\hline Fresh stem weight $(g)$ & 25.34 & 43.39 & $477.83+*$ & 21.92 & 30.04 \\
\hline Root weight (g) & 2.23 & 0.93 & $36.79 * *$ & 3.05 & 2.47 \\
\hline Whole plant weight (g) & 121.68 & 0.63 & $1215.07+*$ & 81.53 & 134.33 \\
\hline Harvest index & 0.01 & $0.02 *$ & $0.04 *$ & 0.01 & 0.01 \\
\hline Dry matter (g) & 1.42 & 0.40 & $41.58 * *$ & 4.94 & 3.44 \\
\hline
\end{tabular}

Whole plant, fresh leaf, stem and root weights and petiole length with high vector score ( $\geq 0.30)$ accounted more for the variation among the accessions along the principal component axis (PA) 1 (Table 3 ). PCA 1 represented $51 \%$ of the cumulative variation of the first three PCAs and PCA2 with 32\% variation was significant for specific leaf area, leaf area and leaf length. Also, considering factor scores above 0.50 to ensure that most characters were loaded once across the factor axes (Table 3), sink factor (fresh leaf, stem, root and whole plant weights, and dry matter) were loaded under factor axis (FA) 1 and photosynthetic-related factor (specific leaf area, leaf area and leaf length) under FA2. Whole plant weight with communality of 0.94 accounted more for the variation across the axes.

The amaranth accessions were classified into seven (7) groups (Table 4). High performance for the sink factors was associated with amaranths in Group 4, and this potential accounted for high dry matter yield of the group. Photosynthetic-related traits were associated with accessions in Group 1. Group 3 had high number of leaves. Distance between the groups was described using the mahalanobis $D^{2}$ distance of the canonical procedure (Figure 1). Groups 4 and 5 were at a significant distance from each other and from the other groups. Distance between groups 2 and 6; 1 and 7; 6 and 7 were not significant.

The ten oligonucleotide primers generated a total number of 115 bands, with 88 (77\%) as the number of polymorphic loci (Table 5). The fragments ranged from 150 to 5500 bp in length. Average PIC value was 0.44 and PIC ranged from 0.31 to 0.50 . The levels of polymorphism revealed by each primer among the accessions ranged from 60\% (OPU-13) to $90 \%$ (OPH-17). The UPGMA dendrogram generated from RAPD primers revealed five main clusters at 0.56 similarity coefficient with many polymorphisms within the clusters (Figure 2). Although, the genetic dendrogram distinguished some of the accessions contrary to the phenotypic diversity, 
Oduwaye et al./ Nig. J. Biotech. Vol. 36 Num. 1: 62-68 (June 2019)

Table 3. Vector scores of characters, variance and eigen value of the first three principal component and factor axes

\begin{tabular}{|c|c|c|c|c|c|c|c|}
\hline \multirow{2}{*}{ Character } & \multicolumn{3}{|c|}{$\begin{array}{l}\text { dXeS } \\
\text { Principal component axis }\end{array}$} & \multicolumn{4}{|c|}{ Factor axis } \\
\hline & 1 & 2 & 3 & 1 & 2 & 3 & Communality \\
\hline Plant height $(\mathrm{cm})$ & 0.19 & 0.12 & 0.12 & 0.40 & 0.21 & 0.17 & 0.32 \\
\hline Stem width $(\mathrm{cm})$ & 0.07 & 0.26 & -0.47 & 0.14 & 0.44 & -0.65 & 0.68 \\
\hline Number of leaves & -0.01 & -0.21 & 0.32 & -0.02 & -0.36 & 0.45 & 0.41 \\
\hline Petiole length $(\mathrm{cm})$ & 0.35 & 0.07 & 0.12 & 0.71 & 0.11 & 0.17 & 0.70 \\
\hline Leaf length $(\mathrm{cm})$ & 0.18 & 0.36 & 0.47 & 0.36 & 0.61 & 0.65 & 0.93 \\
\hline Leaf width $(\mathrm{cm})$ & 0.13 & 0.23 & -0.41 & 0.27 & 0.39 & -0.57 & 0.77 \\
\hline Lear : stem & 0.00 & -0.05 & 0.23 & 0.00 & -0.09 & 0.33 & 0.93 \\
\hline Leaf area $\left(\mathrm{cm}^{2}\right)$ & 0.23 & 0.43 & 0.30 & 0.48 & 0.72 & 0.41 & 0.92 \\
\hline Spedific lear area $\left(\mathrm{cm}^{2} / \mathrm{g}\right)$ & -0.05 & 0.54 & 0.07 & -0.11 & 0.90 & 0.10 & 0.85 \\
\hline Fresh leaf weight (g) & 0.40 & -0.10 & -0.01 & 0.82 & -0.17 & -0.02 & 0.90 \\
\hline Fresh stem weight $(g)$ & 0.38 & 0.01 & -0.24 & 0.78 & 0.02 & -0.34 & 0.94 \\
\hline Root weight (g) & 0.39 & -0.17 & 0.02 & 0.80 & -0.29 & 0.03 & 0.90 \\
\hline Whole plant weight (g) & 0.45 & -0.05 & -0.16 & 0.91 & -0.08 & -0.22 & 0.94 \\
\hline Harvest index & -0.04 & 0.21 & -0.13 & -0.08 & 0.35 & -0.18 & 0.90 \\
\hline Dry matter (g) & 0.28 & -0.35 & 0.10 & 0.58 & -0.58 & 0.14 & 0.76 \\
\hline Eigen value & 4.22 & 2.81 & 1.92 & & & & \\
\hline Variation ( $\%$ ) & 0.28 & 0.19 & 0.13 & & & & \\
\hline Oumulative $(\%)$ & 0.28 & 0.47 & 0.60 & & & & \\
\hline
\end{tabular}

Table 4. Phenotype and character classification of thirty accessions of amaranth

\begin{tabular}{|c|c|c|c|c|c|c|c|}
\hline Ouster & $\begin{array}{c}1 \\
\text { MM19, NG145, } \\
N+1169, \mathbf{N} 1086\end{array}$ & $\begin{array}{c}2 \\
\text { NM06, NM18, NM2Q, } \\
\text { NG011, NG174, } \\
\text { NG184, NG27, N120 } \\
\text { NH151, NH161, } \\
\text { NH3194. }\end{array}$ & $\begin{array}{c}3 \\
\text { MI1, NHI17 } \\
\text { UG4Q }\end{array}$ & $\frac{4}{\text { MMB1,NGOB }}$ & $\frac{5}{N G 016, \text { NG621 }}$ & $\begin{array}{c}6 \\
\text { MM42, NGO14, } \\
\text { NG123, NG132 }\end{array}$ & $\begin{array}{c}7 \\
\text { AOVL NM14 MM32, } \\
\text { NG141, }\end{array}$ \\
\hline Plant height (cm) & $23.92(8.29)$ & $21.97(6.70)$ & $23.85(9.73)$ & $24.16(8.33)$ & $23.96(7.15)$ & $16.21(4.61)$ & $28.95(9.41)$ \\
\hline Stem girth $(\mathrm{cm})$ & $5.47(2.10)$ & $3.98(2.66)$ & $2.81(2.29)$ & $5.15(2.72)$ & $5.87(2.81)$ & $4.05(1.96)$ & $4.60(2.90)$ \\
\hline Number of leaves & $6.98(5.50)$ & $8.04(4.72)$ & $9.64(6.25)$ & $6.45(5.62)$ & $7.43(5.08)$ & $3.90(2.81)$ & $5.52(5.10)$ \\
\hline Petiole length (cm) & $9.99(1.79)$ & $8.54(1.81)$ & $11.08(0.75)$ & $11.06(2.72)$ & $9.19(2.86)$ & $10.26(1.23)$ & $11.45(3.21)$ \\
\hline Leaf length (cm) & $15.48(4.14)$ & $9.09(2.28)$ & $12.87(7.73)$ & $11.32(3.87)$ & $9.22(1.52)$ & $8.32(0.52)$ & $11.12(3.86)$ \\
\hline Leaf width $(\mathrm{cm})$ & $8.60(1.47)$ & $7.92(1.29)$ & $7.87(1.60)$ & $8.84(1.62)$ & $9.37(1.92)$ & $10.01(2.45)$ & $8.41(1.09)$ \\
\hline Leaf area $\left(\mathrm{cm}^{2}\right)$ & $85.33(26.18)$ & $45.95(11.37)$ & $67.46(51.3)$ & $66.54(31.53)$ & $54.73(11.39)$ & $52.99(10.98)$ & $59.55(20.38)$ \\
\hline Specific leaf area $\left(\mathrm{cm}^{2} / \mathrm{g}\right)$ & $19.18(9.08)$ & $8.56(7.10)$ & $10.52(15.41)$ & $6.00(2.64)$ & $15.62(6.59)$ & $12.67(4.13)$ & $8.90(4.47)$ \\
\hline Fresh leaf weight (a) & $7.05(3.35)$ & $5.51(2.93)$ & $11.04(3.23)$ & $12.78(5.55)$ & $8.43(2.35)$ & $7.88(1.40)$ & $9.30(3.52)$ \\
\hline Fresh stem weight ( $\mathrm{q}$ ) & $13.02(5.00)$ & $9.87(3.10)$ & $15.51(4.48)$ & $31.37(12.00)$ & $22.80(17.72)$ & $11.91(4.26)$ & $12.97(5.26)$ \\
\hline Leaf:Stem & $0.56(0.17)$ & $0.55(0.22)$ & $0.72(0.11)$ & $0.45(0.28)$ & $0.55(0.28)$ & $0.71(0.19)$ & $0.75(0.20)$ \\
\hline Root weight (q) & $3.06(1.57)$ & $2.76(1.00)$ & $7.49(2.83)$ & $8.25(3.77)$ & $3.92(2.42)$ & $3.07(1.32)$ & $5.12(2.44)$ \\
\hline Whole plant weight (g) & $23.53(8.32)$ & $19.06(5.78)$ & 34.25 (9.42) & $59.11(29.78)$ & $35.86(19.37)$ & $23.27(5)$ & $27.83(8.02)$ \\
\hline Harvest index & $0.84(0.09)$ & $0.80(0.08)$ & $0.78(0.06)$ & $0.80(0.14)$ & $0.84(0.11)$ & $0.84(0.08)$ & $0.79(0.09)$ \\
\hline Dry mater $(g)$ & $5.29(2.22)$ & $6.86(2.74)$ & $8.62(3.05)$ & $11.18(2.54)$ & $4.05(1.84)$ & $4.38(1.01)$ & $7.51(2.49)$ \\
\hline
\end{tabular}

Standard deviation in parenthesis

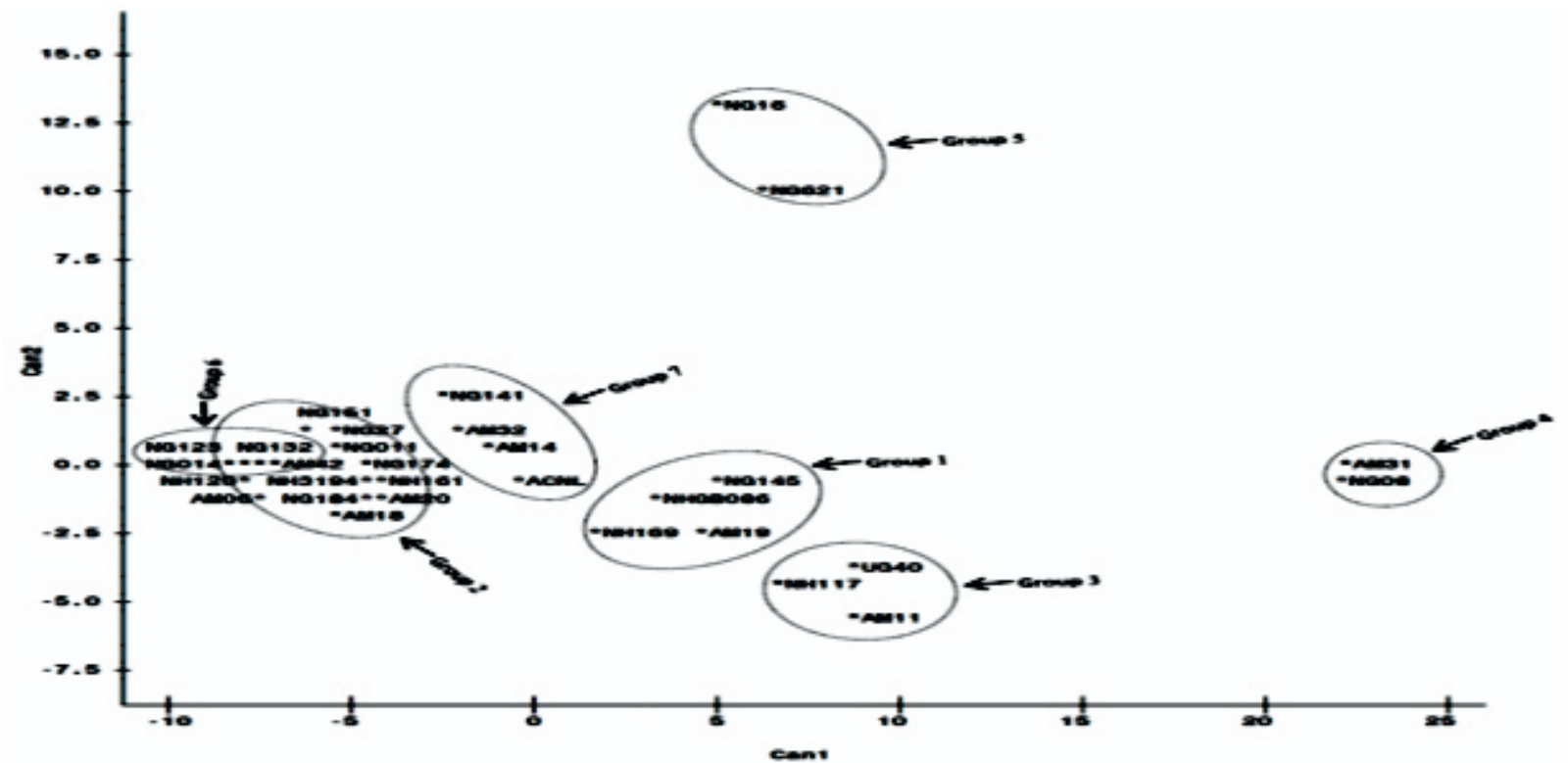

Figure 1. Bi-plot of canonical axes 1 and 2 describing genetic distance between the groups within thirty amaranth accessions 


\section{Oduwaye et al./ Nig. J. Biotech. Vol. 36 Num. 1: 62-68 (June 2019)}

Table 5. Size of band, total number of loci, number of polymorphic loci and polymorphic information content of 10 RAPD primers for 30 accessions of amaranth

\begin{tabular}{lllcc}
\hline Primer & & $\begin{array}{c}\text { Band size } \\
\text { (bp) }\end{array}$ & $\begin{array}{c}\text { Total number } \\
\text { of loci }\end{array}$ & $\begin{array}{c}\text { Number of } \\
\text { Polymorphic loci }\end{array}$ \\
OPB -17 & AGGGAACGAG & $200-1500$ & 16 & 12 \\
information content
\end{tabular}

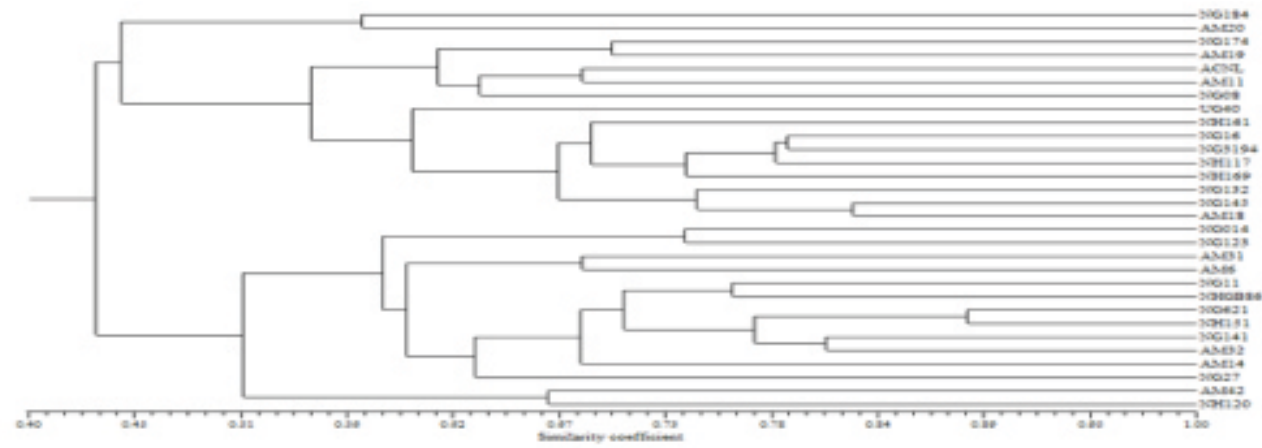

Figure 2. Genetic diversity of thirty accessions of amaranth based on RAPD markers

some information were relatively similar. NG621 was $88 \%$ genetically similar to $\mathrm{NH} 151$; and AM18 was related to NG145 at 0.83 similarity coefficient. NG184 and AM20 were at least $56 \%$ divergent from the other accessions

\section{Discussion}

Amaranth is a common and cheap source of vegetable cultivated in Africa, and it is important for feeding and nutrition of the growing population. Therefore, research efforts to improve and develop new varieties are imperative to provide essential nutrients to consumers whose diets rely heavily on the crop. Part of the effort involves selection of parental materials based on existence of genetic variation.

Among the amaranth in the study, at least, two accessions were different for the characters evaluated. At the early stage of growth of the amaranths, it was possible to identify varying genotypes and select potential parents with high value for the characters. Hence, at the vegetative phase, there is potential for genetic improvement of amaranths which are usually consumed when tender. Studies on vegetable amaranths reported presence of wide range of diversity in both agronomic and qualitative traits (Varalakshmi, 2004; Bola, 2007). Most of the accessions were of green leaf pigmentation and large leaf size which are farmers and consumers preferred traits. Also, differential performance of the accession across years indicated the opportunity to discover and develop superior genotype in varying environmental conditions. Olaniyi (2006) attributed genotype $x$ environment to differences in ecological distribution and genetic differences among the genotypes.

It is not enough to understand genetic variation on individual character but knowledge on genetic divergence, considering several traits simultaneously, is central and valuable in plant breeding. The germplasm can be classified into similar and manageable groups for hybridization processes. Assessment of genetic diversity is mostly and easily accessible by phenotypic variation. Although, often influenced by environmental factors, morphological markers allow for assessment of diversity in the presence of varying environmental conditions. Also, if the traits are heritable phenotypic diversity can reflect the genotypic diversity (Smitha and Krishnakumary, 2011). Advent of molecular markers has also contributed to speedy and reliable information on genetic diversity. It has gain relevance to determine the quality of phenotypic classification relative to genetic diversity (Popa et al., 2010). The morphological divergence and similarity between some of the amaranth accessions reflected the DNA classification. Beyond the grouping pattern, morphological data revealed trait or group of traits that contributed considerably to the diversity. Sink attributes such as leaf, stem and root weights, and dry matter were homogeneous traits and are important as primary selection criteria for vegetative improvement in amaranth. In conclusion, information from the phenotypic diversity can be used deductively with the molecular markers to guide effective hybrid program.

\section{Acknowledgement}

The author recognized the financial support of the Federal University of Agriculture, 


\section{Oduwaye et al./ Nig. J. Biotech. Vol. 36 Num. 1: 62-68 (June 2019)}

Abeokuta, Nigeria through the Tertiary Education Trust Fund (TETFUND) for the research.

\section{References}

Alegbejo, J. O. (2013). Nutritional value and utilization of Amaranthus (Amaranthus spp.) - A review. Bajopas 6(1): 136-143.

Bola, O. 2007. Multivariate analysis of the diversity among some Nigerian accessions of Amaranthus hybridus. Int J Plant Breed Genet 1(2): 89-94.

Chan, K. F. and Sun, M. (1997). Genetic diversity and relationships detected by isozyme and RAPD analysis of crop and wild species of Amaranthus. Theor. Appl. Genet. 95: 865-873.

Doyle, J. J. (1991). DNA protocols for plants CTAB total DNA isolation. In: Hewitt GM (ed) Molecular techniques in taxonomy. Springer, Berlin Heidelberg New York, pp 283-293.

Fracaro, F., Zacaria, J. and Echevemgaray, S. (2005). RAPD based genetic relationships between populations of three chemotypes of Cunila galioides Benth. Biochem Syst Ecol. 33:409-417.

Govindaraj, M., Vetriventhan, M. and Srinivasan, M. (2015). Importance of genetic diversity assessment in crop plants and its recent advance: an overview of its analytical perspectives. Genet. Res. Int. pp14.

Grubben, G. J. H. and Denton, O. A. (2004). Plant Resources of Tropical Africa 2. Vegetables. PROTA Foundation, Wageningen, Netherlands. Backhuys Publishers, Leiden, Netherlands. CTA, Wageningen, Netherlands. 668 pp.

Jaccard, P. (1908). Nouvelles recherches sur la distribution florale. Soc. Vaud. Sci. Nat. Bul. 44: 223-270.

Katiyar, R. S., Shukla, S. and Rai, V. (2000). Varietal performance of grain amaranth (A. hypochondriacus) on sodic soil. Proc. Natl. Acad. Sci. India 70: 185-187.

Mandal, N. and Das, P. K. 2002. Intra- and inter specific genetic diversity in grain Amaranthus using random amplified polymorphic DNA markers. Plant Tissue Cult. Lett. 12: 49-56.

Maundu, P., Achigan-Dako, E. G. and Morimoto, Y. (2009). Biodiversity of African vegetables. In: Shackleton, C. M., Pasquini, M. W and Drescher, A. W. (eds) African indigenous vegetables in urban agriculture. Earthscan, London, pp 65-104.
Olaniyi, J. O. (2007). Evaluation of yield and quality performance of grain amaranth varieties in the southwestern Nigeria. Res. J. Agron. 1(2): $42-45$.

Popa, G., Cornea, C. P., Ciuca, M., Babeanu, N., Popa, O. and Marin, D. (2010). Studies on genetic diversity in Amaranthus species using the RAPD markers. Fascicula Biologie 280-285

Robert, Y. N., Hiroe, K. and Yotaro, K. (2008). Antioxidant activity of various extracts and fractions of Chenopodium quinoa and Amaranthus spp. seeds, analytical, nutritional and clinical methods. Food Chem. 106: 760-766.

Rohlf, F. J. (1998). NTSYSpc Numerical Taxonomy and Multivariate Analysis System vs 2.0. Exeter Software, Setauket, New York.

Roldán-Ruiz, I., Calsyn, E., Gilliland, T. J., Coll, R., van Eijk, M. J. T. and De Loose, M. (2000). Estimating genetic conformity between related ryegrass (Lolium) varieties. 2. AFLP characterization. Mol Breed. 6: 593-602.

SAS Institute, (2000). SAS Linear model: A guide to ANOVA and GLM procedures. SAS Inst., Cary, NC.

Shukla, D., Bhargava1, A., Chatterjee, A., Pandey, A. C. and Kumar, A. R. A. (2010). Genetic interrelationship among nutritional and quantitative traits in the vegetable amaranth. Crop Breed Appl Biot. 10: 16-22.

Smitha, S. and Krishnakumary, K. (2011). Variability in grain amaranth (Amaranthus hypochondriacus). Indian J Agr Sci 81 (5): 476477.

Varalakshmi, B. (2004). Characterization and preliminary evaluation of a vegetable amaranth (Amarnthus sp.), germplasm. PGR Newsletter 137: 55-57.

Williams, J. G. K., Kubelik, A. R., Kivak, K. J., Rafalski, J. A. and Tingey, S. V. (1990). DNA polymorphisms amplified by arbitrary primers are useful as genetic markers. Nucleic Acids Res. 18: 6531-6535.

Winter, P. and Kahl, G. (1995). "Molecular marker technologies for plant improvement," World J Microbiol Biotechnol 11(4): 438-448.

Yeh, F. C., Yang, R. C., Boyle, T. B. J., Ye, Z. H. and Mao, J. X. (1997). POPGENE, the User-Friendly Shareware for Population Genetic Analysis. Molecular Biology and Biotechnology Center, Alberta. 